\title{
An Econometric Assessment of Entrepreneurship in the Diamond Mining Sector and Its Impact on Economic Growth in Sierra Leone
}

\author{
Abdulai Salia Brima \\ Lecturer \\ Department of Economics and Commerce, Fourah Bay College, University of Sierra Leone \\ Sesay Brima \\ PhD Research Scholar \\ School of Economics, Wuhan University of Technology, Wuhan 430070, P.R. China
}

\begin{abstract}
This study examines the relationship between entrepreneurship in the diamond mining sector and economic growth in Sierra Leone for the period 1970-2013. The neoclassical production function is employed to explore new firm formation in the mining sector as a separate determinant of economic growth. Using recent econometric technique, the study finds a unique co-integrating relationship among real GDP, entrepreneurship, labour and capital. The results suggest that entrepreneurship exerts a positive and statistically significant effect on economic growth, and investment in the diamond mining sector is an important channel through which entrepreneurs fuel economic growth. Policy recommendation calls for entrepreneurship education, improving on the general labour capacity, facilitating access to finance, improving support services and the employment conditions for entrepreneurship.
\end{abstract}

Keywords: Entrepreneurship, diamond sector, economic growth, co-integration, Sierra Leone

DOI: $10.7176 /$ RHSS/9-7-05

Publication date: April $30^{\text {th }} 2019$

\section{Introduction}

The concept of entrepreneurship has a wide range of meanings. On the one hand, an entrepreneur is a person of very high aptitude who pioneers change, possessing characteristics found in only a very small fraction of the population. On the other hand, anyone who wants to work for himself/herself is considered to be an entrepreneur. Entrepreneurship places an emphasis on innovation, such as: new products, new production methods, new markets and new forms of organization. Wealth is created when such innovation results in new demand. From this view point, one can define the function of the entrepreneur as one of combining various input factors in an innovative manner to generate value to the customer with hope that this value will exceed the cost of the input factors, thus generating superior returns that result in the creation of wealth.

Sierra Leone is one of the countries richly endowed with abundant natural resources in the world. Such resources include diamonds, gold, bauxite, rutile, platinum, iron ore, etc. The country was in 2010, the world's $10^{\text {th }}$ largest producer of diamonds (2010 Minerals Yearbook Sierra Leone) while earlier on, in 2007, the country was the 7th largest producer of diamonds in the world. Sierra Leone like other countries in the region is currently undergoing the process of state building, which includes increasing state capacity to provide services to its people and improve the business environment. The government has recently in 2012 introduced a National Mines Agency to further support the industry. However, unregistered mining organizations are unlikely to benefit from this move.

Sierra Leone is a post-conflict state that is seeking to develop its international trading sectors, including the extractive industries. In the process, the state struggles to deal with the large informal segment of the economy involved in mining business. The miners represent 'bottom of the pyramid' entrepreneurs who are part of a global commodity chain.

The links between resource governance and post-conflict reconstruction covers a number of issues, including the fight against corrupt practices inherited from war-time political elites, and initiatives to render the commodity chain of so called 'conflict minerals' more transparent.

The lack of information regarding the global market and rules regarding participation in domestic mining has been an issue with many of the miners. Hence, it is critical to assess how successful the government is in articulating its rules, but also maintaining its avenues of support.

This study is introducing a new dimension by exploring the strength of the relationships and networks within this industry and looking at how these entrepreneurs face a number of 'formal and informal constraints' that act upon each other.

The link between entrepreneurship and economic growth remains a relatively under-researched 
phenomenon in developing countries. Statistics show that informal mining is a strong sector in Sierra Leone; however, disconnect exists between how the state views the miners and how the miners view themselves in the role of the national economy. The miners are marginalized due to their unregistered status; the output of these miners eventually enters the legal market through brokers. Few miners interviewed claimed that they had nothing to do with the state. This could be because they perceive the state's purpose and goals as being out of reach or out of touch with their own purposes and goals. This study therefore examines the possibility of entrepreneurship in the diamond sector, and its effect on economic growth in Sierra Leone. The central research question is: How can formal entrepreneurship in the diamond mining industry contribute to economic growth and development in Sierra Leone?

The rest of the paper is organized as follows: Section 2 provides brief review of diamond sector and economic growth in Sierra Leone. In section 3, both theoretical and empirical literatures are reviewed; section 4 contains the data sources, methodology, and empirical results. Section 5 concludes the paper.

\section{Brief Review of the Diamond Sector and Economic Growth in Sierra Leone}

Since the early 1930s, the mining sector has contributed immensely to the country's economy. Diamonds, rutile, bauxite, and iron ore are presently mined by major mining companies after a disruption of about 10 years, from 1995 to 2005, owing to the civil war. The country's proven diamond fields spread over an estimated area of nearly 20,000 square kilometers, which is more than $25 \%$ of the country.

As a result of the mining sector, the growth of real gross domestic product (RGDP) increased from $6 \%$ in 2011 to $16.7 \%$ in 2012 (figure1). Before this period, real GDP growth was 3.2\% in 2009 and increased to 5\% in 2010. Sierra Leone's dependence on the mining sector is replicated by its huge impact to GDP (20 percent) and recorded exports (90 percent) during the 1990s. After the war in 2002, the contribution of the mining sector to the country's GDP is presently about $30 \%$. Prior to the start of the war in 1991, mining was by far the most significant foreign exchange earner for the country. Foreign exchange income is still overwhelmingly dependent upon a single product, diamonds, which accounted for 34\% of (regular) export earnings in 2009. An additional $24 \%$ of export earnings were credited to rutile and bauxite, which had only been resuscitated from their wartime collapse in 2006. Fiscal revenues' reached a maximum of around 8 percent of GDP in 1990 but degenerated to less than 2 percent after the closure of two important mines in 1994 owing to the civil conflict in the country. Mining's significance to fiscal revenue increased substantially with the reopening of the two closed mines as well as the opening of the kimberlite diamond mine in 2003. And significantly exceed the production and export figures before the civil conflict.

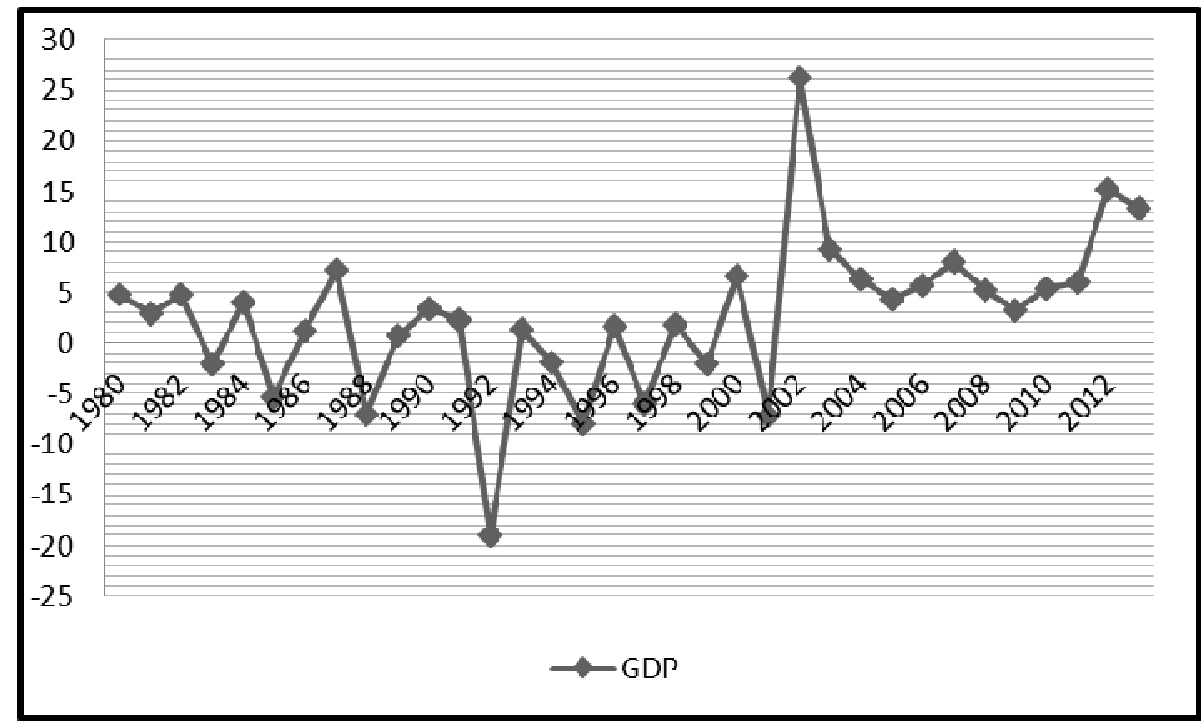

Figure 1; Real GDP growth, 1980-2013(per cent)

As at present, the most important commodity to the economy of Sierra Leone is diamonds. In 2010, the country was the 10th largest producer of diamonds in the world, with a yearly production of approximately 440.000 carats. The country, in 2010, also exported in excess of 550.000 carats valued at around 130 MUSD. Earlier on, in 2007, the country was the 7th largest producer of diamonds in the world (see table 1 below). 
Table 1: Major African Diamond Producers in 2007

\begin{tabular}{|c|c|c|}
\hline Country & US\$ (million) & \% of World Production \\
\hline 1. Botswana & $2,960.14$ & 24.50 \\
\hline 2. $\quad$ South Africa & $1,417.33$ & 11.70 \\
\hline 3. $\quad$ Angola & $1,271.96$ & 10.50 \\
\hline 4. Namibia & 748.05 & 6.20 \\
\hline 5. Democratic republic of Congo & 609.83 & 5.00 \\
\hline 6. Lesotho & 164.07 & 1.40 \\
\hline 7. $\quad$ Sierra Leone & 141.57 & 1.20 \\
\hline 8. Central African Republic & 59.86 & 0.50 \\
\hline 9. Guinea & 50.20 & 0.41 \\
\hline 10. Tanzania & 28.50 & 0.24 \\
\hline 11. Ghana & 27.86 & 0.23 \\
\hline 12. Zimbabwe & 23.38 & 0.20 \\
\hline 13. Liberia & 2.70 & 0.02 \\
\hline 14. Togo & 1.24 & 0,01 \\
\hline Total & $7,506.65$ & 62.08 \\
\hline
\end{tabular}

Source: Partnership Africa Canada, Diamonds and Human Security Annual Review 2008, Ottawa, Canada

Regardless of the fact that the country has been among the top 10 diamond producing countries in the world, it has constantly been ranked at the bottom side of the UN Human Development Index throughout the previous few decades. However, there has been an improvement in the HDI in recent years.

Also, table 2 below shows the exports of diamonds from $1998-2006$.

Table 2: Diamond exports from Sierra Leone: 1998 - 2006 (GGDO)

\begin{tabular}{|l|c|c|c|}
\hline Year & Carats & Value (US\$) & Duty: 3\% (US\$) \\
\hline $\mathbf{1 9 9 8}$ & $15,818.04$ & $1,780,287.41$ & $53,480.22$ \\
\hline 1999 & $9,320.32$ & $1,244,825.34$ & $37,344.76$ \\
\hline 2000 & $77,372.39$ & $10,066,920.81$ & $302,007.62$ \\
\hline 2001 & $222,519.83$ & $26,022,492.27$ & $780,674.77$ \\
\hline 2002 & $341,859.23$ & $41,732,130.29$ & $1,251,964.71$ \\
\hline 2003 & $506,723.37$ & $75,969,753.32$ & $2,193,335.84$ \\
\hline $2004(+)$ & $499,242.43(\mathrm{~A})$ & $89,618,053.54$ & $2,688,541.60$ \\
\hline $2004(+)$ & $58,030.54(\mathrm{~K})$ & $11,172,434.79$ & $335,173.04$ \\
\hline 2005 & $552,044(\mathrm{~A})$ & $119,429,528$ & $3,582,885.84$ \\
\hline 2005 & $116,665(\mathrm{~K})$ & $22,510,716$ & $675,321.48$ \\
\hline $2006(*)$ & $209,762(\mathrm{~A})$ & $45,535,966$ & $1,366,078.98$ \\
\hline $2006(*)$ & $30,631(\mathrm{~K})$ & $6,984,425$ & $209,532.75$ \\
\hline
\end{tabular}

Note: $(+)=$ Figures from January to September 2004, $(*)=$ Figures from January to June 2006, (A) = Alluvial, $(K)=$ Kimberlite. Source: Strasser King (2004:9) and GGDO Diamond Export figures, 2001-2006

From table 2 above, one can see that the value of diamonds exported dropped from around USD $1.7 \mathrm{~m}$ in 1998 to USD $1.2 \mathrm{~m}$ in 1999 during the heights of the civil war. From the year 2000 to 2005, the export value of diamonds increased gradually from around USD $10 \mathrm{~m}$ to USD $119.4 \mathrm{~m}$ in 2005 . This increment in the value of exports could be attributed to the end of the civil war in the country. However, in 2005 for example, irrespective of the high value of Diamonds exported (US\$119,429,528), the country was just able to receive US\$3,582,885.84 as duty (see table 2).

Additionally, the implementation of the Kimberly Process Certification Scheme (KPCS), a regulatory mechanism, has aided the improvement and management of the diamond industry in Sierra Leone significantly. Before the year 2000, the joint effect of the war and the absence of good management of the minerals sector lead to the government losing substantial revenue from its minerals resources. By 2000, however, the civil war had subsided, and with the implementation of the KPCS, the total value of exports of diamonds increased. By 2012, the export value had risen to US\$163.2m.

\section{Literature Review}

\subsection{Theoretical Literature}

The emergence of entrepreneurship development rest on two important factors, i.e. innovation and resources mobilization, (Baumol, 1990) according to him, innovation lies at the hub of entrepreneurship activities, which aid at transforming raw materials into finish goods. Thus develop resources for economic growth and development. An entrepreneur is one who always searches for change, responds, to it and exploits opportunities. What lies at the heart of resource utilization and usage is the mentality of technological development, innovation 
and development of entrepreneurship skills.

Entrepreneurship is a scheme which has informed policy makers and provides alternative approach to poverty alleviate (Hart, 2007; Peredo and Cherisman, 2006), particularly in developing countries, where socioeconomic groups have experienced social exclusion, 'the denial of equal access to opportunities' (Behrman et al., 2003). This form of entrepreneurship can be termed 'social entrepreneurship', where entrepreneurs play the role of change agents by developing a mission to create and sustain social and private value (Peredo and Cherisman, 2006).

The need for entrepreneurship may be particularly important in underdeveloped regions where economic and social problems are more acute, and governments have been constrained by corruption and lack adequate resources to address these problems. Baumol (1990) distinguishes between productive, unproductive and destructive entrepreneurship activities. A key idea in defining unproductive and destructive entrepreneurship is that not everything that is entrepreneurial is necessarily desirable.

Productive entrepreneurship "Refers, to an activity that contributes directly or indirectly to net output of the economy or to the capacity to produce additional output" (ibid). Foss et al (2010) add to this by introducing the element of new discovery, referring to "productive entrepreneurship" as the discovering of new attributes, opportunities, procedures and the like, where the discovery leads to increase in joint surplus. Productive entrepreneurs are similar to Schumpeter's (1934) 'innovative' entrepreneurs, those that discover new resources and create products that did not previously exist. They are however not synonymous with Kirzner's (1997) 'alert' entrepreneurs- those able to see and act on previously unnoticed profit opportunities, which, according to Shane (2003), differs from Schumpeterian entrepreneurs by being less dependent on knowledge creation but rather on the exploitation of existing information, and thus much more common. Shane (2003) argues that alertness is dependent upon cognitive capabilities of individuals; such as high intelligence and creativity. Furthermore, an outcome of high corruption, social instability and weak public sector institutions, discussed by North (1990), Sachs (2005), and Stiglitz (2002), may actually direct the entrepreneur towards knowledge sources that lead to destructive outcomes such as smuggling. Alertness is thus necessary for productive outcomes, but not sufficient. Weak institutional settings may channel alert entrepreneurs away from productive activities, especially if entrepreneurship policies are not carefully developed. Stiglitz (2002), for example, argues that countries with weak public-sector institutions are unlikely to benefit from economic integration into the global economy.

Destructive entrepreneurship is where detrimental activities such as criminal behaviour lead to net social loss. Often, an entrepreneur makes no productive contribution to the real output of an economy, and in some cases even plays a destructive role Baumol (1990). This happens when the structure of payoffs in an economy is such as to render unproductive activities such as rent seeking more profitable than productive activities (ibid). In this light Baumol (1990) argues that the allocation of resources to either productive or unproductive use varies across societies. Weak and unstable formal institutions as well as norms and societal values might foster unproductive entrepreneurship (Baumol, 1990; Smallbone and Welter, 2001). Unproductive entrepreneurship involves activities that do not create socially beneficial improvements, but instead seek rents through, for example, the exploitation of legal loopholes. Unproductive and destructive entrepreneurship can take many forms Baumol (1990). These include but not limited to, rent seeking, illegal and shadow activities, and different forms of corruption.

Another facet of entrepreneurial activities is risk-taking. To implement an entrepreneurship, an entrepreneur has to accept the risk that his investment of money, time and energy may not pay off. Much new work confirms that entrepreneurs are less risk-averse than others. Gentry et al (2002) show that entrepreneurs have poorly diversified portfolios. Puri and Robinson (2004) use U.S. survey data to show that entrepreneurs are unusually risk-loving and optimistic.

Baumol (1990) assumes the supply of entrepreneurial talent is roughly constant, where growth is largely determined by institutions that encourage productive, unproductive, or destructive outcomes. Such argument confirms North's (1990) observation that economic growth is driven by the incentive structures that encourage individual effort and investment, which in turn is determined by institutions, i.e. society's 'rules of the game', the establishment of which shapes future productive structures (Bygrave and Minniti, 2000).

According to Fogel et al, (2005) the factors that determine the abundance of entrepreneurs are the following:

1. Rules, regulation and property right, and their enforcement matter; because they affect what we call transactional trust: the degree of trust the parties to business transaction place in each other.

2. Government matters; because it establishes and enforces rules, regulations, and property rights. Good government raises transactional trust and so facilitates entrepreneurship. Insufficient government fails to protect the rights of the weak, and this discourages entrepreneurship. Cumbersome regulations and burdensome rules can raise the costs of running a new business to the point where acquiring the skills needed to be an entrepreneur seems pointless. 
3. Culture matters, for the literature shows that authoritarian and hierarchical societies fail to honour selfmade success, and social status is surely part of the payoff to entrepreneurs.

4. Very basic institutions matter profoundly. Universal basic education lets latent entrepreneurs realize that opportunities exist.

These institutional constraints are fundamentally important, and a deficit in any can impede entrepreneurships throughout a region, a country, or a civilization. To clarify this, the economics of entrepreneurship is explored more deeply and then provide some preliminary empirical investigation of the validity of these arguments.

Many institutional features that influence entrepreneurship, like laws and regulations, are directly controlled by the state and hence by those who influence it. Others, like law enforcement and judicial efficiency, are heavily influenced by the state. Yet others, like culture and religion, probably lie outside the control of the state, except perhaps in the very long run. This may explain why some emerging economies, like China and Poland seem more entrepreneurial than others.

The institutional factors that most significantly affect entrepreneurship probably depend on an economy's stages of development. For example, state-of-the-art accounting disclosure rules are of little use in an economy where most of the population is illiterate or judges are irredeemably corrupt.

Entrepreneurial activity in low-income developing countries often entails an individual setting up a small business to earn a living. At this stage, the state can promote entrepreneurial activity by offering entrepreneurs secure ownership of their business, legal enforcement of business contracts they enter, basic communication and transportation infrastructure, and an educated population from which to hire.

This can promote economic growth as small business owners and employees develop business skills and the broader society comes to appreciate their achievements. Individuals who succeed in these endeavours save from their earnings and invest further in the human capital of their children, in their own businesses or more broadly. The last creates opportunities for developing a financial system, which extends entrepreneurial career opportunities to people lacking personal or family wealth. This sows the seed for the next stage of development and for more intense entrepreneurial activity.

\subsection{Empirical Literature}

Acs and Armington (2002) also used the American regional data in their study to link entrepreneurship to economic growth at the regional level using new firm birth rate as a direct measure of entrepreneurial activity to economic growth in each of these local economics and found that higher levels of entrepreneurial activity were significantly and positively linked to higher economic growth rates.

However, Audretsch and Fritsch (1994) found contrasting result for Germany during the 1980s. In their findings for the manufacturing and the service sectors, a high rate of entry-exit in a region tended to lead to a lower and not a higher rate of economic growth for Germany. The explanation they gave for this contrast in results between Germany and the U.S.A was that regional growth came from SMEs only when they served as agents of change through innovative activity.

Furthermore, Audretsch and Fritsch (2002) found in their repeat study for the 1990s that those regions with higher start-up rates exhibited higher economic growth rates. The possible explanation being that the engine of growth had then shifted towards entrepreneurship for Germany. Audretsch and Fritsch (2002) reviewed studies linking entrepreneurship to economic growth for the five large economies (France, Germany, Japan, U.K., U.S.A.) and found that the manufacturing industry that underwent only little downsizing in the 1977-90 period experienced relatively less subsequent growth for these countries. Reynolds (1999), Acs and Armington (2002), Audretsch and Fritsch (2002) concluded that both new-firm start-up rates and exit rates contributed significantly and positively to the growth of total factor productivity in regions and industries.

Carree and Thurik (2011) examined the impact of the share of small firms in manufacturing industries in European countries in 1990 and found that they had a positive and significant effect on the industrial output growth. Further, their findings indicated that excess growth of small firms had a positive influence on percentage change in growth of national product for a sample of 16 European countries from 1988 to 1993.

Desai, Gompers and Lerner (2003) gauge entrepreneurship in European Union members and Central and Eastern European countries using entry rates, average firm size, a greater average firm age, and a more symmetric size distribution as evidence of more active entrepreneurs. Using these measures, they report more entrepreneurship in less corrupt countries and in countries that better protect private rights. They also show a less consistent link between less interventionist courts and more entrepreneurial activity.

Desai, Gompers, and Learner (2003) report that these same "regulatory burdens" data correlate positively with higher average firm sizes in European countries, indicating that the burdens probably protect large incumbents' market shares. "Regulatory burdens" are positively correlated with entry in Central and Eastern European countries, but this may be a statistical artifact of an unusual negative correlation between regulatory burden and corruption in those countries. 
Wong et al (2005) defined the augmented Cobb-Douglas model to examine the impact of innovation on economic growth for 37 countries participating in the General Entrepreneurship Monitor (hereafter, GEM) data set. They used ordinary least squares in their estimation and found that innovation was positively related to GDP growth. However, they did not find support for their second hypothesis that a higher level of overall Total Entrepreneurship Activity (TEA) was related to higher economic growth rates. The distinctive result from their study was that of the four types of new business creation activities, only high potential entrepreneurship was found to have a significant impact on economic growth. In addition, they conducted an analysis to determine if the effect of new business creation on economic development was moderated by the income level of nations and found the income effect had insignificant impact on economic growth. In addition, they conducted an analysis to determine if the effect of new business creation on economic development was moderated by the income level of nations and found the income effect as insignificant in their model.

Using the same GEM dataset but a different model specification, Van Stel et al. (2004) analyzed the impact of changes in capital, labour, Research and Development (hereafter, R \& D) activities and entrepreneurships on economic growth for German regions between 1990 and 2002 and found that growth differed for counties in different stages of economic development.

The results indicated that an increase in the region's knowledge stock generated by R \& D carried out in private business was a fundamental determinant of economic growth because regions increased their knowledge stock through R \& D activities in private and public industries compared to their initial stronger economic growth rate. Like Wong et al. (2005), Van Stel et al. (2004) found that innovative start-up activity had a bigger impact on economic growth than an increase in general start-up activity.

Audstretch and Keilbach (2004) hypothesized that regions with greater degree of entrepreneurship capital exhibited higher output for German regions, ceteris paribus. They measured entrepreneurship using business start-ups from 1989-1992, a ten year period, to take care of stochastic disturbances but computed two modified measures of entrepreneurship; one restricted entrepreneurship capital to include only start-up activity in hightechnology manufacturing industries (whose R \& D - intensity is above $2.5 \%$ ) while the second restricted entrepreneurship capital to start-ups in ICT industries, firms in the hard and software business, and convincingly captured the argument by some scholars that entrepreneurship should only refer to start-ups involving innovative activity.

Their findings confirmed that physical capital, labour, knowledge, High-Tech and ICT entrepreneurship were significant determinants of output for German regions. Audstretch and Keilbach (2004) further regressed output on only one of each of these two alternative measures of entrepreneurship capital and confirmed their initial findings by other scholars that entrepreneurship was indeed a major determinant of economic growth.

Henderson (2006) distinguished his study from others by disaggregating entrepreneurship into two major measures of entrepreneurship based on proprietor data levels as follows: the average share of non-farm employment in the country accounted for by non-farm proprietors, the average annual growth rate in entrepreneurs where three measures of entrepreneurship were used to test the hypothesis namely: the average number of per capital new business start-ups, the average number of per capital new business that survived five years, the average number of per capital new business start-ups that produced high growth during the first five years of operation.

The framework for modeling the possibility of entrepreneurship emphasized role of entrepreneurship in the creation and growth of firms. The favourable conditions required to trigger the entrepreneurial process are captured as "favourable environment for entrepreneurship" in the conceptual framework. The existence of this favourable business environment will result in the emergence of entrepreneurial opportunities.

In addition to the conducive business environment and macroeconomic conditions, their entrepreneurial actions are also influenced by cultural factors and institutional factors as captured in the conceptual framework. Wennekers et al (2005) argued that the history of the rise and fall of nations has shown that cultural vitality, thriving sciences and high tide in entrepreneurship often coincided. Further, the institutional framework both on the national level and within firms importantly defined the incentives for individuals to turn their ambitions into actions and determined to what extent unnecessary barriers would hamper them.

Entrepreneurs realize their entrepreneurial qualities and ambitions by establishing business start-ups, coming up with innovations or entering new markets. This is shown in the conceptual framework. Caree et al (2002) found that the activities of the total number of individuals with entrepreneurial ability that decided to start their own firms, directly affected economic growth and development. The impact of these entrepreneurial activities is depicted in the fourth section as improved personal wealth at the individual level, high profitability at the firm level and creation of jobs, high rates of competitiveness and economic growth at the macro level. There is often competition of new ideas and initiates which lead to variety in the market and survival and imitation of the most viable firms on one hand and a displacement of obsolete firms on the other. At the macro level, this leads to expansion and transformation of the productive potential of the national economy by inducing higher productivity and an expansion of new niches and industries (Caree et all 2002, pp. 19-20). 
The model adopted for this study has been similarly tested by Audstretch et al. (2002) and Henderson (2006) for the German and Brazilian regions respectively. In both work, gross domestic product was postulated to be a function of capital, labour, knowledge capital and entrepreneurship. Wennekers et al. (2005) also used an adapted version model to regress GDP as measured by per capital income on nascent entrepreneurship. Wong et al. (2005) used a related model to analyze the impact of entrepreneurial activity on economic growth for 37 countries participating in the GEM 2002. It was later adapted by Aloysius (2002) for Cameroun and in other Africa Economic Research Consortium (hereafter, AERC) funded papers examining the African economic growth performance. Entrepreneurs realize their entrepreneurial qualities and ambitions by establishing business start-ups, coming up with innovations or entering new markets (Caree et al, 2002).

\section{Data and Methodology \\ 4.1 Data Source}

This study uses secondary data mainly. Data for the measure of Entrepreneurship, 'Enter', the total number of registered mining companies as at end of year, their starting capital and labour employed by each company were collected from the Sierra Leone Registry and Administrative office in Freetown.

Data for Real Gross Domestic Product (RGDP) were collected from the publications of the World Bank, and the Central Bank of Sierra Leone. Nominal Gross Domestic Product data are converted to real values using the GDP deflator. The data collected is annual in nature and spanned over a 50 year period from 1970-2013. There were few structural breaks in series for the component of entrepreneurship data. However, estimates were built-up by taking average data for the component through interpolation using SPSS.

\subsection{Methodology}

The study uses an econometric technique in regressing economic growth on its explanatory variables through the following procedures: testing for stationarity properties of the variables using the Augmented Dickey Fuller and the Phillip-Perron unit root test followed by Johansen's co-integration test to check for the existence of cointegrating and long run relationships. Consequently, the error correction model was employed to estimate the error correction term and short run relationship. Finally, diagnostics test was also conducted to determine the robustness of the adopted model. Following literatures reviewed, the model was specified to take the following neoclassical production form:

Where,

$$
\mathrm{Y}=\mathrm{AK}^{\alpha} \mathrm{L}^{1-\alpha}
$$

$\mathrm{Y}=$ is output in the economy which has been proxied as GDP

$\mathrm{K}=$ is the factor of capital

$\mathrm{L}=$ is the factor of labour

$\mathrm{A}=$ is labour augmented technology or knowledge which has been proxied as a measure of entrepreneurial activities in the diamond sector.

Transforming equation (1) to an econometric form to reflect our modified model gives:

$$
\mathrm{GDP}_{\mathrm{t}}=\alpha_{0}+\beta_{1} \mathrm{~K}_{\mathrm{t}}+\beta_{2} \mathrm{~L}_{\mathrm{t}}+\beta_{3} \text { Enter }_{\mathrm{t}}+\varepsilon_{\mathrm{t}}
$$

The log-log model has been employed to estimate the elasticity (degree of responsiveness) of economic growth (GDP denoted as Y) with respect to labour (L), capital (K), entrepreneur (Enter), and political instability (War) which was included as a dummy variable to capture the period of war (1991-2001=1 and 0 otherwise). Thus equation (2) was rewritten as:

$$
\operatorname{lnGDP} t=\alpha_{0}+\beta_{1} \ln K_{t}+\beta_{2} \operatorname{lnL} L_{t}+\beta_{3} \operatorname{lnEnter}{ }_{t}+\beta_{4} \text { War }_{t}+\varepsilon_{t}
$$

Where $\alpha_{0}$ is a constant, $\beta_{1}-\beta_{4}$ are parameters to be estimated and $\varepsilon_{t}$ is the error term. The a priori expectations of the model are that $\beta_{1}, \beta_{2}, \beta_{3}>0$ and $\beta_{4}<0$. The model is estimated with the aid of E-views 7.2 software.

\subsubsection{Unit Root Tests}

The first step in our analysis is to check for unit root. This test was done to determine the order of integration for each variable in the model. A variable is said to have a unit root if it is non-stationary at level but can became stationary after first differencing-integrated of order one. The order of integration of each series was established using the Augmented Dickey-Fuller (ADF) and Phillips-Perron (PP) tests. The ADF test equation is given as:

$$
\begin{gathered}
\Delta \mathrm{x}_{\mathrm{t}}=\alpha+\delta \mathrm{x}_{\mathrm{t}-1}+\ldots \sum \delta_{\mathrm{i}} \Delta \mathrm{x}_{\mathrm{t}-1}+\ldots \delta_{\mathrm{m}} \Delta \mathrm{x}_{\mathrm{t}-\mathrm{m}}+\varepsilon_{\mathrm{t}} \\
\Delta \mathrm{x}_{\mathrm{t}}=\alpha+\beta_{\mathrm{t}}+\delta \mathrm{x}_{\mathrm{t}-1}+\ldots \sum \delta_{\mathrm{i}} \Delta \mathrm{x}_{\mathrm{t}-1}+\ldots \delta_{\mathrm{m}} \Delta \mathrm{x}_{\mathrm{t}-\mathrm{m}}+\varepsilon_{\mathrm{t}}
\end{gathered}
$$

Equation (4) includes an intercept and no trend, while equation (5) includes intercept and time trend. $\alpha_{0}$ is a constant, $\delta$ is a coefficient of autoregressive process, $\Delta$ is the difference operator, $t$ is a time trend, $x_{t}$ is the variable under consideration, $m$ is the number of lags and $\varepsilon_{t}$ is the stochastic error term. The lagged differences of the variables are augmented to the test model in order to mitigate autocorrelation problems in the disturbance term. The Akaike Information Criterion (AIC) and Schwarz Bayesian Criterion (SBC) are used to determine the optimal lag length $\mathrm{m}$ in the above equations.

The Phillip-Perron test equation is similar to the Augmented Dickey-Fuller test but the lag m, is omitted to 
adjust for the standard error in view to correct for heteroskedasticity and autocorrelation. Consequently The PP test equation is specified as:

$$
\Delta \mathrm{x}_{\mathrm{t}}=\alpha+\beta_{\mathrm{t}}+\delta \mathrm{x}_{\mathrm{t}-1}+\ldots \sum \delta_{\mathrm{i}} \Delta \mathrm{x}_{\mathrm{t}-1}+\varepsilon_{\mathrm{t}}
$$

The tests rely on rejecting the null hypothesis of a unit root (the series are non-stationary) in favor of the alternative hypothesis of no unit root (the series are stationary). If the absolute values of the ADF and PP test statistics are greater than the critical values, we reject the null hypothesis of non-stationary and conclude that the series is stationary. On the other hand, if the absolute values of the ADF and PP statistics are less than the critical values, we fail to reject the null hypothesis and conclude that the series is non-stationary. These tests results are presented in table 3 and 4.

Table3: Augmented Dickey-Fuller Test

\begin{tabular}{|c|c|c|c|c|c|}
\hline \multirow{2}{*}{ Variable } & \multicolumn{2}{|c|}{ Level } & \multicolumn{2}{c|}{ First Difference } & \multirow{2}{*}{ Order of Integration } \\
\cline { 2 - 5 } & t-Statistic & ADF Statistic & t-Statistic & ADF statistic & \\
\hline InRGDP & -3.518090 & -0.285779 & -3.520787 & $-6.486040^{* *}$ & $\mathrm{I}(1)$ \\
\hline InEnter & -3.520787 & -1.624808 & -3.520787 & $-3.969618^{* *}$ & $\mathrm{I}(1)$ \\
\hline $\ln \mathbf{n}$ & -3.520787 & -0.640374 & -3.520787 & $-3.906957^{* *}$ & $\mathrm{I}(1)$ \\
\hline $\ln \mathbf{L}$ & -3.518090 & -2.763957 & -3.520787 & $5.606276^{* *}$ & $\mathrm{I}(1)$ \\
\hline War & -3.518090 & -1.509602 & -2.933158 & $-6.324555^{* *}$ & $\mathrm{I}(1)$ \\
\hline
\end{tabular}

Note: $* *$ and $* * *$ : indicate significant at $5 \%$ and $10 \%$ levels respectively

Table 4: Phillip-Perron Test

\begin{tabular}{|c|c|c|c|c|c|}
\hline \multirow{2}{*}{ Variable } & \multicolumn{2}{|c|}{ Level } & \multicolumn{2}{c|}{ First Difference } & \multirow{2}{*}{ Order of Integration } \\
\cline { 2 - 5 } & t-Statistic & PP Statistic & t-Statistic & \multicolumn{1}{c|}{} \\
\hline InRGDP & -3.518090 & -0.722377 & -3.520787 & -6.618731 & $\mathrm{I}(1)$ \\
\hline InEnter & -3.518090 & -2.637050 & -3.520787 & -3.981083 & $\mathrm{I}(1)$ \\
\hline InK & -3.518090 & -0.033656 & -3.520787 & -3.825498 & $\mathrm{I}(1)$ \\
\hline InL & -3.518090 & -2.934126 & -3.520787 & -5.542433 & $\mathrm{I}(1)$ \\
\hline War & -3.518090 & -1.590147 & -3.520787 & -6.307073 & $\mathrm{I}(1)$ \\
\hline
\end{tabular}

Note: $* *$ and $* * *$ : indicate significant at $5 \%$ and $10 \%$ levels respectively

The unit root test result for both the Augmented Dickey Fuller and Phillip-Perron tests reveal that all the variables in the model were non-stationary at their level but became stationary at first differencing. Thus the variables are integrated of order one, denoted as I(1). This suggests the use of co-integration analysis since the concept of co-integration requires variables must be integrated of same order.

\subsubsection{Co integration Test}

Given that the variables are integrated of the same order, the co-integration analysis is appropriate to estimate the long run model. Thus the significant issue is to determine the number of co-integrating vectors. Johansen and Juselius $(1988,1990)$ suggested the use of two statistical tests which are the trace test $\left(\boldsymbol{\lambda}_{\text {trace }}\right)$ and the maximum eigen value test $\left(\boldsymbol{\lambda}_{\max }\right)$. These two tests are estimated with the aid of the following equations:

$$
\begin{aligned}
& \lambda_{\text {trace }}(\mathrm{r})=-\mathrm{T} \sum_{\mathrm{j}=\mathrm{i}+1}^{\mathrm{n}} \ln \left(1-\hat{\lambda}_{\mathrm{i}}\right) \\
& \lambda_{\text {max }}(\mathrm{r}, \mathrm{r}+1)=-\mathrm{T} \ln \left(1-\hat{\lambda}_{\mathrm{r}+1}\right)
\end{aligned}
$$

Where

$\boldsymbol{\lambda}_{\text {trace }}$ test the null hypothesis $r=0$ against the alternative of $r>0$

$\mathrm{T}=$ number of usable observations

$\lambda_{\mathrm{i}}=$ Eigen values or estimated characteristics root

$\lambda_{\max }$ test the null hypothesis $r=0$ against the alternative of $r=1$

If the null hypothesis of no co-integrating vector is rejected, it indicates that there is a long-run relationship among the variables in the model. These test results are presented in table 5 and 6 . 
Table: 5. Unrestricted Co-integration Rank Test (Trace)

\begin{tabular}{|c|c|c|c|c|}
\hline $\begin{array}{c}\text { Hypothesized } \\
\text { No. of CE(s) }\end{array}$ & Eigen value & $\begin{array}{c}\text { Trace } \\
\text { Statistic }\end{array}$ & $\begin{array}{c}0.05 \\
\text { Critical Value }\end{array}$ & Prob. $^{* *}$ \\
\hline None $^{*}$ & 0.716987 & 129.1800 & 95.75366 & 0.0000 \\
\hline At most 1 & 0.659696 & 87.52533 & 69.81889 & 0.0010 \\
\hline At most 2 & 0.530075 & 51.95411 & 47.85613 & 0.0196 \\
\hline At most 3 & 0.409044 & 27.03311 & 29.79707 & 0.1008 \\
\hline At most 4 & 0.175254 & 9.674662 & 15.49471 & 0.3066 \\
\hline
\end{tabular}

Source: E-views output

Table: 6. Unrestricted Co-integration Rank Test Result (Maximum Eigen value)

\begin{tabular}{|c|c|c|c|c|}
\hline $\begin{array}{c}\text { Hypothesized } \\
\text { No. of CE(s) }\end{array}$ & Eigen value & $\begin{array}{c}\text { Max-Eigen } \\
\text { Statistic }\end{array}$ & $\begin{array}{c}0.05 \\
\text { Critical Value }\end{array}$ & Prob.** \\
\hline None $*$ & 0.716987 & 41.65467 & 40.07757 & 0.0329 \\
\hline At most 1 $*$ & 0.659696 & 35.57122 & 33.87687 & 0.0311 \\
\hline At most 2 & 0.530075 & 24.92099 & 27.58434 & 0.1056 \\
\hline At most 3 & 0.409044 & 17.35845 & 21.13162 & 0.1558 \\
\hline At most 4 & 0.175254 & 6.358427 & 14.26460 & 0.5677 \\
\hline
\end{tabular}

Source: E-views output

The values of both the trace statistics (129.1800) and the Max-Eigen statistic (62.65297) are greater than their critical values at 5\% significant level of (95.75366) and (33.87687) respectively and their corresponding probability values are less than $5 \%$, which implies that we reject the null hypothesis of no co-integrating relationship at the 5\% significant level. Moreover, whiles the trace test statistics is showing at least three cointegrating equations the maximum eigen test statistics is showing two.

The presence of co-integration implies that long run equilibrium relationship exists between the dependent variables and the explanatory variables. Hence the hypothesis that long-run equilibrium relationship between entrepreneurship and economic growth exits in Sierra Leone is supported. The long run regression model is presented in table 7 below.

Table7: Results of Estimated Long-Run Relationship

Dependent Variable: GDP

\begin{tabular}{|c|r|r|r|r|}
\hline Variable & Coefficient & Std. Error & t-Statistic & Prob. \\
\hline C & 27.47273 & 0.203824 & 134.7866 & 0.0000 \\
\hline $\ln K$ & 0.082356 & 0.007278 & 11.31564 & 0.0000 \\
\hline $\ln L$ & -0.012378 & 0.013289 & -0.931497 & 0.3573 \\
\hline lnEnter & 0.146633 & 0.024401 & -009372 & 0.0000 \\
\hline War & -0.173750 & 0.023055 & -7.536286 & 0.0000 \\
\hline R-squared & 0.942074 & Mean dependent var & 29.14730 & \\
Adjusted R-squared & 0.936133 & S.D. dependent var & 0.227408 & \\
S.E. of regression & 0.057470 & Akaike info criterion & -2.768447 & \\
Sum squared resid & 0.128811 & Schwarz criterion & -2.565698 & \\
Log likelihood & 65.90583 & Hannan-Quinn criter. & -2.693258 & \\
F-statistic & 158.5674 & Durbin-Watson stat & 2.264736 & \\
Prob(F-statistic) & 0.000000 & & \\
\hline
\end{tabular}

Source: E-views output

The positive coefficient of 27.47273 (intercept), indicates that when the independent variables in this model are all equal to zero (i.e. Enter, K, L and War), the expected earnings of the GDP is about 27.47 billion Leones. This implies that a level of GDP is attainable even at zero value of the explanatory variables.

Furthermore, the magnitudes (coefficients) as shown in the second column of table 7 above, of capital $\left(\mathrm{l}_{\mathrm{n}} \mathrm{K}=0.082356\right.$ or $\left.8.2 \%\right)$ is positive and statistically significant which implies that a one percent increase in capital input in the mining sector will induce GDP growth by approximately $8.2 \%$. however, labour $\left(l_{n} \mathrm{~L}=-\right.$ 0.012378 or $-1.2 \%$ ) impacts on gross domestic product is very small and insignificant for the study. This may be due to the large level of unskilled labour and low level of capital investment in the mining sector. Unlike labour, the positive sign of capital $\left(l_{\mathrm{n}} \mathrm{K}\right.$, ) variable supported the theoretical conclusion that Capital contribute positively to GDP growth.

The result further showed that, the coefficient of Enter is positive (0.146633) and statistically significant which means that a 1 percent increase in entrepreneurial activity (Enter) in the mining sector, leads to approximately $1.5 \%$ increase in GDP growth. Also, the statistically significant coefficient conforms to the theoretical expectations. This is not surprising since it is expected that Entrepreneur enhances knowledge and 
skill, thereby resulting in growth. Political instability (war) was introduced in the model as a dummy variable to see how the civil war impacted GDP growth and hence it was found to be negative, which implies a negative impact of the civil war on economic growth in Sierra Leone.

The adjusted $\mathrm{R}^{2}=0.936133(93.61 \%)$ would imply that $93.61 \%$ total variation in economic growth (RGDP) is explained by the regression independent variables. This indicates that about $93.61 \%$ of the total systematic variation in real GDP is jointly explained by the variation in all the explanatory variables and the remaining $6.39 \%$ could be attributed to the stochastic error term not included in the model.

The Durbin-Watson statistic provides a range between $(1.95 \leq \mathrm{d} \leq 2.5)$ for the non-existence of autocorrelation. The DW statistic 2.26 in table 7 above is observed to be within the standard range, indicating that the model has an economic meaning and thus reliable for interpretation.

\subsubsection{Estimation of Error Correction Model (ECM)}

The Error Correction Model (ECM) is a restrictive auto regressive model that can be used to estimate nonstationary time series that were identified to be co-integrated. It is designed in such a way that it restricts the long-run behavior of the independent variables to meet to their co-integrating relationship and at the same time allow for short-run correction. This can also be explained with the help of the following equation:

$$
\Delta \mathrm{X}_{\mathrm{z}}=\gamma_{0}+\gamma_{1}+\Delta \mathrm{Y}_{\mathrm{t}}+\lambda \mathrm{V}_{\mathrm{z}-1}+\varepsilon_{\mathrm{z}}
$$

Substituting equation (3) into equation (9) to incorporate the error correction term to reflect the short-run dynamics yields:

$$
\Delta \operatorname{lnGDP}=\alpha_{0}+\sum_{\mathrm{i}-2}^{\mathrm{q}} \beta_{1} \Delta \ln K_{\mathrm{t}-\mathrm{j}}+\sum_{\mathrm{i}-2}^{\mathrm{q}} \beta_{2} \Delta \ln \mathrm{L}_{\mathrm{t}-\mathrm{i}}+\sum_{\mathrm{i}-2}^{\mathrm{q}} \beta_{3} \Delta \ln \text { Enter }_{\mathrm{z}-\mathrm{j}}+\sum_{\mathrm{i}-2}^{\mathrm{q}} \beta_{4} W_{\mathrm{ar}} \mathrm{z}-\mathrm{j}
$$

Where $\Delta$ is the first difference operator, $\mathrm{q}$ is the lag length, $\boldsymbol{\lambda}$ is the speed of adjustment and $\mathrm{ECM}_{\mathrm{t}-1}$ is the lagged error term and all other variables are described as earlier.

Given that the series are integrated of order one I(1) and co-integrated, justifies the use of the Error Correction Model to capture the short-run dynamics of the model. The short-run relationship among the variables is tested and the result is presented in table 8 below:

Table 8: Result of the Error Correction Model

Dependent Variable: GDP

\begin{tabular}{|c|r|r|r|r|}
\hline Variable & \multicolumn{1}{l|}{ Coefficient } & \multicolumn{1}{l|}{ Std. Error } & t-Statistic & Prob. \\
\hline C & 27.84902 & 0.326694 & 85.24487 & 0.0000 \\
\hline$\Delta \operatorname{lnK}$ & 0.061979 & 0.013512 & 4.587005 & 0.0001 \\
\hline$\Delta \operatorname{lnL}$ & -0.006238 & 0.013138 & -0.474833 & 0.6377 \\
\hline$\Delta \operatorname{lnEnter}$ & 0.115021 & 0.039447 & 2.915791 & 0.0060 \\
\hline War & -0.194970 & 0.027796 & -7.014356 & 0.0000 \\
\hline ECM(-1) & -0.349953 & 0.133932 & -2.612912 & 0.0145 \\
\hline R-squared & 0.949021 & Mean dependent var & 29.15338 & \\
Adjusted R-squared & 0.942132 & S.D. dependent var & 0.226454 & \\
S.E. of regression & 0.054475 & Akaike info criterion & -2.853364 & \\
Sum squared resid & 0.109798 & Schwarz criterion & -2.607616 & \\
Log likelihood & 67.34734 & Hannan-Quinn criter. & -2.762740 & 1.954898 \\
F-statistic & 137.7590 & Durbin-Watson stat & & \\
Prob(F-statistic) & 0.000000 & & \\
Source: E-views & & & \\
\end{tabular}

\section{Source: E-views output}

The short run error correction result confirms that there is a direct positive and highly significant relationship between gross domestic product and entrepreneurship. This means, by considering the period under study, entrepreneurship is found to be a determinant factor of economic growth.

The probability value $(0.0060)$ in the short-run error correction regression model confirms that the coefficient for the measure of entrepreneurship, 'Enter' is significant at the $5 \%$ level. Thus, the coefficient 0.115021 in column 2 of table 8 indicates that a 1 percentage increase in entrepreneurship in the diamond mining sector increases GDP growth by approximately $11.5 \%$. In summary, the short run result is in conformity with the long run result. The coefficient of the error correction term indicates the speed of adjustment in eliminating deviation from the long run equilibrium. The coefficient has the expected negative sign $(-0.349953)$ and it is statistically significant at the 5\% level. The significance of the coefficient further confirms the existence of the long run relationship between economic growth and the $\mathrm{I}(1)$ variables under consideration. The magnitude of the 
coefficient implies that nearly $35 \%$ of the disequilibrium in the previous year's shock adjusts back to long run equilibrium in the current year. The value of the DW statistic $d=1.954898$ is within the appropriate range $(1.95 \leq \mathrm{d} \leq 2.5)$ indicating no autocorrelation.

\subsubsection{Diagnostic Test}

To ascertain the goodness of fit of the estimated model, the diagnostic test was conducted. Diagnostic test suggests that the model passes the test of serial correlation, functional form misspecification, non-normality of the errors and heteroscedasticity associated with the model.

Table 9 of the regressions includes diagnostic statistics for testing against various alternative hypotheses. Table 9: Diagnostics Test Result

\begin{tabular}{|c|c|c|c|c|}
\hline Test Type & Null Hypothesis & Statistic & Probability & Inference \\
\hline $\begin{array}{l}\text { Normality Test } \\
\text { (Jarque-Bera Statistics) }\end{array}$ & $\begin{array}{l}\text { Errors are normally } \\
\text { distributed }\end{array}$ & $\begin{array}{l}\text { Jarque-Bera } \\
\text { Statistics = } \\
0.862052\end{array}$ & $\begin{array}{l}\text { Probability } \\
0.64984\end{array}$ & $\begin{array}{l}\text { Fail to } \\
\text { reject Ho }\end{array}$ \\
\hline $\begin{array}{l}\text { Serial Correlation } \\
\text { (Breush-Godfrey Serial } \\
\text { Correlation LM Test) }\end{array}$ & $\begin{array}{r}\text { No serially } \\
\text { correlated errors }\end{array}$ & $\begin{array}{l}\text { F-statistics } \\
0.9547\end{array}$ & $\begin{array}{lr}\text { Prob. } & \text { Chi- } \\
\text { Square } & = \\
0.113703 & \\
\end{array}$ & $\begin{array}{l}\text { Fail to } \\
\text { reject Ho }\end{array}$ \\
\hline $\begin{array}{l}\text { Heteroskedasticity Test } \\
\text { (Breush-Pagan-Godfrey) }\end{array}$ & $\begin{array}{l}\text { Homoskedastici } \\
\text { ty }\end{array}$ & $\begin{array}{l}\text { F-statistics } \\
0.7939\end{array}$ & $\begin{array}{lr}\text { Prob. } & \text { Chi- } \\
\text { Square }=0.2583\end{array}$ & $\begin{array}{l}\text { Fail to } \\
\text { reject Ho }\end{array}$ \\
\hline $\begin{array}{l}\text { Model Specification Test } \\
\text { (Ramsey RESET Test) }\end{array}$ & $\begin{array}{c}\text { Model is } \\
\text { correctly specified }\end{array}$ & $\begin{array}{l}\text { F-statistics } \\
=1.35765\end{array}$ & $\begin{array}{l}\text { Probability }= \\
0.643431\end{array}$ & $\begin{array}{l}\text { Fail to } \\
\text { reject Ho }\end{array}$ \\
\hline
\end{tabular}

Source: E-views output

The diagnostic test suggests good fit of the model. The model does not suffer from the problems of nonnormality of the errors, serially correlated errors, heteroskedasticity and functional form misspecification from the values in table 9.

\section{Conclusion and Recommendations \\ 5.1 Conclusion}

The main objective of the study was confirmed; that there is a significant positive relationship between real gross domestic product and entrepreneurship. The findings indicated that entrepreneurship was an important determinant of economic growth for the period under study. The coefficient of entrepreneurship, "Enter", which is a measure of the total number of mining businesses as at end of year, was significant at $5 \%$. The measure of capital was significant at the $1 \%$ level while that for labour was insignificant in both the short and long run. Unlike labour, the signs for the coefficients of capital and entrepreneurship were all positive and as expected indicative of a positive relationship with Real Gross Domestic product

Also, the negative impact of political instability on economic growth reflects the long rebel war that caused serious harm to the country. In the 1990s, there was a significant increase in TNCs' investment in developing countries. While many countries were beginning a process of international economic integration and implementing policies to attract investors, Sierra Leone was consumed by war. Foreign investors, with the exception of few mining companies, largely bypassed Sierra Leone when considering investment opportunities in Africa. The government should strengthened the political institutions and continue to adopt democratic principles that will ensure stability within the economy

The adjusted R-squared values were over $90 \%$ in both the short and long run indicating that the independent variables in the regression model collectively explained over $90 \%$ of all variations of Real Gross Domestic product. Only less than $10 \%$ of the determinants were captured by the error term.

\subsection{Recommendations}

The government and other stakeholders should put in place measures that create a good environment that will encourage the creation and growth of new mining businesses as these create jobs and are major agents of entrepreneurship. Some of the measures that government and stakeholders should take should include:

* The government and Private sector should invest in training entrepreneurs by facilitating the development of entrepreneurship courses in the public and private institutions that would equip the general labour with requisite skills and knowledge to be more productive in the dynamic mining business environment.

* The government and other stakeholders should improve on technology transfer, raising domestic capital stock, and also foster cooperation between Small and Medium Enterprises (SMEs) and the banking institutions as this will enhance further support to capital accumulation in the sector. New policies for capital formation in Sierra Leone will promote capital productivity in the mining sector.

* Entrepreneurs in the sector should ensure that they offer basic skills training for workers employed to improve on their performance. Also ensure that every worker should have a tool to work with. 
Entrepreneurs should avoid a mismatch between workers and the available equipment to improve their performance and thus enabling labour to contribute to the overall economic growth.

* Fora should be created where businesses can exchange good practices. This should include but not limited to government improving dialogue with mining communities and make it easy for mining businesses to find answers to access support services, and hence improving the long-run association between entrepreneurship and economic growth.

However, this paper has only examined the relationship between economic growth and entrepreneurship in the mining sector in Sierra Leone. Any further research on this issue should consider the Socio-economic and environmental impact of the operations of mining companies in the diamond sector. In addition to looking at the nexus between economic growth and entrepreneurship in the mining sector, the authors recommend that further studies look at how mining entrepreneurs are benefiting from state mining policies.

\section{References}

Acs, Zoltan J. and Armington Catherine, (2002) "Entrepreneurial Activity and Economic Growth" An Empirical Analysis", Paper prepared for the Kaufman Foundation.

Acs, Z. \& Virgill, N., (2010). Entrepreneurship in Developing Countries. In Z. Acs \& D.B. Audretsch, eds. Handbook of Entrepreneurship Research. International Handbook Series on Entrepreneurship. New York and London: Springer, pp. 485-515.

Acs, Z., Desai, S. \& Hessels, J., (2008). Entrepreneurship, Economic Development and Institutions. Small Business Economics, 31 (3), pp. 219-234.

Acs, Zoltan J (2006), "Entrepreneurship is good for Economic Growth" Innovations, Winter, pp 97-107

Acs, Zoltan J. and David Audretsch (1987), "Innovation in Large and Small Firms: An empirical Analysis". America Economic Review

Aloysius Ajab Amin (2002), “An examination of the sources of economic growth in Cameroon”. AERC Growth Project

Armington C. and Acs Zoltan J. (2002) "The determinant of regional variation in new firm formation. Regional Studies 36(1), pp. 33-45

Audretsch, D.B and Thurik A.R (2001b) "Linking entrepreneurship to growth", STI working paper 2001/2, Paris: OECD.

Audretsch D. and Keilbach M. (2004) "Entrepreneurship capital and economic performance", Centre for Economic Policy Research Discussion Paper DP 3678, London: CEPR.

Audretsch David and Fritsch Michael (1994). On the Measurement of Entry rates; Empirica, February 1994, Volume 21, Issue, pp 105-113

Audertsch David and Fritsch Michael (2002), "Growth regimes over time and space" Regional studies 36, 113124.

Baumol, W.J. (1990), "Entrepreneurship: productive, unproductive and destructive". Journal of Political Economy, 98, 893-921

Behrman, J., Gavira, A. and Szekely, M. (2003). Who's In and Who's Out: social exclusion in Latin America. Washington, DC: Inter- America Development Bank.

Blanchflower, D.G. (2000), "Self-employment in OECD countries", Lobour Economis7, pp, 471-505

Bryman, A. and Cramer, D., 2009. Constructing Variables. In M. A. Hardy \& A. Bryman, eds. The Handbook of Data Analysis. London, UK: Sage Publications Ltd, pp. 17-34.

Bygrave, W., and Minniti, M. (2000) "The social dynamics of entrepreneurship" Entrepreneurship: Theory \& Practice, 24, 25-36

Bosman Niels and Nieuwenhuijzen Van Niels (2002); Turbulence and Productivity; An Analyis of 40 Dutch Regions in the period 1988-1996. Scales paper N200205

Caree Martin, Andre Van Stel, Roy Thurik and Sader Wennekers (2002), "Economic development and Business Ownership: An Analysis Using Data of 23 OECD Countries in the period 1976-1996". Small Business Economics 19(3), pp. 271-290

Carree, M. and Thurik. R, (2011). The Impact of Entrepreneurship on Economic Growth. In Z. Acs and D. Audretsch, eds. Handbook of Entrepreneurship Research. New York, NY, USA: Springer, pp.557- 594.

Caves, R.E (1998), "Industrial organization and new findings on the turnover and mobility of firms", Journal of economic literature 36(4), pp, 1947-1982

Coase, Ronald, (1937), “The Nature of the Firm” Economica, Vol, 4 Iss. 16(Nov) 386-405).

Cuvelier, J. (2013). 'Conflict minerals in eastern Democratic Republic of Congo: planned interventions and unexpected outcomes', in: D. Hilhorst, Disaster, conflict and society in crisis: everyday politics of crisis response, London: Routledge, pp 132-148

Dasai, Mihir, Paul Gompers, and Josh Lerner, (2003), "Institutions, Capital Contraints and Entrepreneurial Firm Dynamics: Evidence from Europe, NBER Working Paper No. 10165 
De Soto, Hernando, (1990), The Other Path, New York, NY: harper and Row.

De Soto, Hernando, (2000), The Mystery of Capital: Why Capitalism Triumphs in the West and Fails Everywhere Else, New York: Basic books

Dickey D., W. A. Fuller (1981), "Likelihood ratio statistics for autoregressive time series with Unit root", Econometrica, vol.49, No.4, Evanston, Illinois.

Engle, Robert F. and Granger, C.W.J (1987), "Cointegration and Error Correction: Representation, Estimation, and Testing," Econometrics, 55, 251-76.

Fogel, K., Hawk A., Mock R. and Yeung Bernard (2006). Institutional Obstacles to Entrepreneurship. In M. Casson el al., eds. The Oxford book of Entrepreneurship. Oxford, UK: Oxford University Press, pp. 540579.

Fogel, Kathy, (2004), "Oligarchic Family Control and the Quality of Government”. Working paper

Fogel, Kathy, Randall Morck, and Bernard Yeung, (2005). "Corporate Stability and Economic Growth: Is what's Good for General Motors Good for America?” paper presented at America Finance Association 2005 meetings.

Foss Nicolai, Husted Kenneth and Michailova Snejina (2010). Governing Knowledge sharing in Organisations: Levels of Analysis, Mechanisms and Research Discussions. Journal of Management Studies.

Gentry, William, and Glen Hubbard, (2002) "Entrepreneurship and Household savings," Advances in Economic Analysis and Policy, Berkely Electronic Press, Fortcoming. (Previous version: National Bureau of Economic Research, Working Paper No. 7894, September 2002.

Granger, C.W.J (1986). Developments in the Study of Cointegrated Economic Variables. Oxford Bulletin of Economics and Statistics, 48(3), 213-228

Engle, Robert F. and Granger, C.W.J (1987), "Cointegration and Error Correction: Representation, Estimation, and Testing," Econometrics, 55, 251-76.

Grant, J. (2005). 'Salone's sorrow: the ominous legacy of diamonds in Sierra Leone', in M. Basedau and A. Mehler (eds.), Resource politics in Sub-Saharan Africa, Hamburg: Institute of African Affairs: 259-281

Hart, S. (2007). "Capitalism at the Crossroads. Upper Saddle River, NJ: Pearson Educational/Wharton School Publishing

Hayek, Friederich A. (1948), Institutionalism and Economic order, London: Routledge and Kegan Paul.

Hayek, Friedrich A. von (1937), "Economics and Knowledge", Economica, Feb vol. 4 pp. 33-54.

Henderson Jason (2006), "Understanding rural entrepreneur at the county level: data challenges". Presented at the frameworks for Enterpreneurship Research in Food, Agricultural and Rural Development workshop. Federal Review Bank of Kansaa City.

Houman Anderson, P. and Skaates, M.A., (2004). Ensuring Validity in Qualitative International Business Research. In Handbook of Qualitative Research Methods for International Business. Cheltenham, UK: Edward Elgar Publishing Ltd, pp. 464-485.

Iyer, R., (2009). Entrepreneurship identities and the problematic of subjectivity in media-mediated discourse. Discourse \& Society, 20(2), pp. 241- 263.

Kirzner, I. M., (1973). Competition and Entrepreneurship, Chicago, US: University of Chicago Press.

Kirzner, Isreal M.,(1997), " Entrepreneurial Discovery and the Competitive Market Process: an Austrian Approach, “ Journal of Economics Literature, 35(1), March, 60-85

Licht, A. \& Siegel, J., (2006). The Social Dimensions of Entrepreneurs. In M. Casson et al., eds. The Oxford handbook of Entrepreneurship. Oxford University Press, pp.511-539.

North, D.C., (1990). Institutions, Institutional Change and Economic performance, Cambridge University Press.

North, Douglas C. (1990) Institutions, Institutional Change, and Economic Performance, Cambridge University Press, New York

Peredo, A.M and Cherisman J.J (2006). "Towards a theory of community-based enterprise" Academy of Management Review, 31, 309-28

Phan Phillip, Zhou Jing and Abrahamson Eric (2010). Creativity, Innovation, and Entrepreneurship in China. Management and Organization Review, 6(2), pp. 175-194.

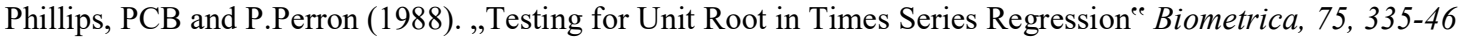

Pijpers, R., (2011). When Diamonds go Bust: Contextualizing Livelihood Changes in Rural Sierra Leone. Journal of International development, 23(8), pp. 1068-1079.

Puri, Manju and David T. Robinson (2004) “ Optimum, Work/Life Choices, and Entrepreneurship," paper presented at the Worldbank-Stern -NYU Entrepreneurship workshop, World Bank, Jan 10, 2005.

Reynolds, P.D. (1999), “Creative destruction: source or symptom of economic growth?”, in Acs, Z.J., Carlsson, B. and Karlesson, Ch. (eds), , Entrepreneurship, Small and Medium-Sized Enterpries and the Macroeconomy Cambridge: Cambridge University Press, pp. 97-136

Sachs, J. (2005) The End of Poverty. London: Allen Lane.

Schumpeter, J.A., (1934). Theory of Economic Development New edition, Brunswick, NJ: Transaction 
Publishers.

Schumpeter, Joseph A. (1934) The Theory of Economic Development (Trans. Redvers Opie), Cambridge, MA: Harvard University Press.

Schumpeter, Joseph A. (1942) Capitalism, Socialism and Democracy, $3^{\text {rd }}$ edition, New York: Harper \& Bros.

Shane, S. (2003). A General Theory of Entrepreneurship: The Individual-Opportunity Nexus. Cheltenham: Edward Elgar

Shane, S. and Venkataraman, S. (2000) "The promise of entrepreneurship as a field of research". Academy of Management Review, 25, 217-26

Smallbone, D. and Welter, D. (2001). "The distinctiveness of entrepreneurship in transition economics". Small Business Economics, 16, 249-55

Stiglitz, J. (2002). "Employment, social justice and social well-being". International Lobour Review, 141, 9-29

Tyson, L. d'Andrea, Petrin, T. and Rogers, H., (1994). Promoting entrepreneurship in Eastern Europe. Small Business Economics, 6(3), pp. 555-184.

Valente, M. and Crane, A.(2010) " Public responsibility and private enterprise in developing countries" California Management Review, 25, 439-45

van Stel, A.J and D.J Storey (2004), "The Link between Firm Births and Job Creation: Is there a Upas Tree Effect?” Regional studies38, pp. 893-909

Webb, J.W., Kistruck, G., Ireland, D. and Ketchen, D, (2010). The Entrepreneurship process in Base of the Pyramid Markets: The Case of Multinational enterprise/Nongovernment Organization Alliances. Entrepreneurship Theory and Practice, 34(3), pp.555-581.

Webb, Kistruck, G., Ireland, D. and Ketchen, D. (2010). "The entrepreneurship process in the base of the pyramid market: the case of multinational enterprise/nongovernmental organization alliances". Entrepreneurship Theory and Practice, 34, 555-81

Wenneker, A.R.M, A.R. Thurik, R. and Reynolds, P. (2005), "Nascent Entrepreneurship and level of Economic Development", Small Business Economics, 24, pp. 293-309

Wong, Po Kam, Yuen Ping Ho and Erkko Autio (2005), "Entrepreneurship, innovation and economic growth: evidence from GEM data", Small Business Economics24 (3), pp. 335-350

Yang, Y.J. and Li, J., (2008). The Development of Entrepreneurship in China. Asia Pacific Journal of Management, 25(2), pp. 335-359. 